\title{
Adaptation of Teaching-Learning Models Due to Covid-19 Pandemic: Challenge Towards Teachers Problem-Solving Skills
}

\section{Erni Munastiwi1}

${ }^{1}$ Sunan Kalijaga State Islamic University Yogyakarta, Indonesia

\section{A R T I C L E I N F O}

Article history:

25 December 2020

Received in revised form

01 January 2021

Accepted 25 January 2021

Available online 03

Pebruari 2021

Kata Kunci:

blended learning, perbaikan, prasarana dan sarana, hambatan

Keywords:

blended learning, improvements,

infrastructures and

facilities, obstacles

\begin{abstract}
A B S T R A K
Pandemi covid-19 sangat berdampak pada dunia pendidikan. perubahan sistem pembelajaran berpengaruh pada proses pembelajaran. Permasalahan muncul dirasakan oleh para pendidik wilayah kebun sawit Kalimantan Timur terkait sarana penunjang pembelajaran online. Keterbatasan jaringan maupun alat komunikasi menjadi masalah tersendiri dalam mencerdaskan anak bangsa di masa pandemi covid-19. Penelitian ini bertujuan untuk mengidentifikasi strategi, metode, hambatan dan solusi guru dalam memecahkan masalah di masa pandemi covid-19. Penelitian dilakukan melalui metode kualitatif, dengan melibatkan tiga guru Sekolah Dasar. Teknik pengambilan data observasi, wawancara, dan dokumentasi. Uji keabsahan data dengan triangulasi sumber subjek penelitian tiga pendidik di SD Teladan Prima Benua Baru dan SD Teladan Prima 01. Analisis data menggunakan Miles \& Huberman terdiri dari tiga alur kegiatan yang terjadi secara bersamaan yaitu: reduksi data, penyajian data, penarikan kesimpulan. Hasil penelitian menunjukkan kendala yaitu kepemilikan smartphone, tidak tersedianya jangkauan jaringan untuk
\end{abstract} internet, TV, dan radio, materi ajar terbatas, jarak rumah siswa, disiplin siswa, keterbatasan orangtua dalam mendampingi anak belajar, dan keterbatasan waktu. Strategi pemecahan masalah guru meliputi melaksanakan blended learning, membuat kelompok belajar, kunjungan rutin kepada siswa, menggandeng orang tua, adaptasi rencana pengajaran, optimalisasi media elektronik, dan pemanfaatan media kreatif. Demikian, aspek keterampilan memecahkan masalah penting dimiliki oleh para pendidik.

\section{A B S T R A C T}

Pandemic covid-19 has a significant impact on the world of education. Changes in the learning system affect the learning process. The problem arises felt by educators of east Kalimantan palm oil plantations related to online learning support facilities. Network limitations and communication tools become a separate ר problem in educating the nation's children during the covid-19 pandemic. This study aims to identify strategies, methods, obstacles, and solutions for teachers in solving problems during the covid-19 pandemic. The research was conducted through qualitative methods, involving three elementary school teachers. Observation data retrieval techniques, interviews, and documentation. Test the data's validity by triangulation the sources the research subjects of three educators in Teladan Prima Benua Baru and Teladan Prima 01 elementary schools. Data analysis using Miles \&Huberman consists of three activities that coincide: data reduction, data presentation, conclusion drawing. The results showed obstacles, namely smartphone ownership, the unavailability of network coverage for the internet, TV, radio, limited teaching materials, student home distance, student discipline, parental limitations in accompanying children to learn, and time constraints. Teacher problem-solving strategies include implementing blended learning, creating learning groups, regular visits to students, partnering with parents, adapting teaching plans, optimizing electronic media, and utilizing creative media. Thus, aspects of problem-solving skills are essential for educators. 


\section{Introduction}

Education is a field that undergoes significant changes due to the Covid-19 pandemic. The impact of the changes in education does not only affect teachers and students but also parents as well as school managers. Garbe et al. (2020, p. 45) found that parents were having hardship in balancing responsibilities, providing motivation, gaining access, and evaluating the learning outcomes of their children. School managers on the other side need to formulate strategies to cope with the disruption in education to restore its educational function (Karalis, 2020, p. 139). Many countries had applied various policies to hinder physical contact to suppress the rate of virus transmission, such as physical distancing, stay at home, lockdown, as well as a social limitations (Benke, Autenrieth, Asselmann, \& Pané-Farré, 2020; Koh, Naing, \& Wong, 2020; Marroquín, Vine, \& Morgan, 2020). Later, a prolonged pandemic had driven many countries to implement the "new normal" policy (Tria, 2020), referring to the precaution of viral transmission along with the recovery of economic activities (Berawi, 2020). Unfortunately, after approximately one year, the cure for Covid-19 is not found yet. Therefore, people are forced to continue living in the "new normal" way.

The "new normal" implies that activities that involve crowds are restricted, including school activities (Tria, 2020). Therefore, teaching/learning activities should be done online. However, various problems arose due to the sudden change of teaching/learning method, such as ownership of smartphone or computer, data plan subscription, network limitation, limitation of learning media, etc. (Lassoued, Alhendawi, \& Bashitialshaaer, 2020, p. 8; Muhdi, Nurkolis, \& Yuliejantiningsih, 2020, pp. 251-252; Rasmitadila et al., 2020, p. 92). As the result, students could not learn effectively. Moreover, the obligation to provide facilities for students to learn also became a burden to parents (Inawati \& Setyowati, 2020, p. 126; S. Ma, Sun, \& Xue, 2020, p. 1). Not only in Indonesia, in China as a Chinese citizen, complaining and not yet trained with online learning (Dong, Cao, \& Li, 2020)

Primary school education on the other side is a crucial stage in education. Children are experiencing a transformation from non-formal to formal education (Skouteris, Watson, \& Lum, 2012, p. 78), from affective learning to cognitive learning (X. Ma, Shen, Krenn, Hu, \& Yuan, 2016, p. 777). Therefore, teachers' role is crucial. During this stage, children are less dependent on their parents but still not ready to be a self-learner. Teachers' guidance is the most dominant part. As the result, children's skills receive significant effects from the teachers, such as social, behavioral, and even cognitive (Jennings \& DiPrete, 2010, p. 151).

Teachers should have problem-solving skill is the skill teachers need to have in order to be able to deliver appropriate education to the students (Mutlu Göcmen \& Gülec, 2018, p. 52; Yavuz, Arslan, \& Gulten, 2010, p. 1631). The outbreak of the Covid-19 pandemic had been lasting for nearly one year. Practically, it cost two whole semesters in Indonesia's education system. During the last two semesters, there is a probability that teachers adapt to the changing education environment and developed their own strategies to overcome the obstacles in teaching-learning activity. Teachers are responsible to facilitate and perform interesting learning activities (Prestiadi, 2020, p. 51).

Previous research studies on teachers in solving learning problems during the covid-19 pandemic, first, have been conducted in universities such as the completion of chemical learning with the strategy of Learning, Practicing, Collaborating, and Assessing (DLPCA) is an effective strategy in mixed online instruction at undergraduate Chemistry courses at the University of Santo Tomas Philippines (Lapitan, Tiangco, Sumalinog, Sabarillo, \& Diaz, 2021). Second, the creativity of elementary school teachers in India in solving learning problems in the online learning period is by using dolls, storytelling, energizers, in online inclusion classes, in addition teachers are more innovative and professional in teaching pandemic times to reduce the digital gap in India with the right standard virtual platform for marginalized families (Khanna \& Kareem, 2021), third, seair model in school teaching planning during the pandemic (Gandolfi, 2021).

In the study of previous literature studies in 2020-2021 above on solving learning problems during the covid-19 pandemic. There are various studies on the use of learning problem-solving methods in 3 different countries. Previous research produced a variety of other ways in each country with varying levels of education. In this research article, the researcher observed and analyzed that this research article was able to complement and add to the literature study on methods and problem solving of teachers in teaching in the countryside with many shortcomings of online learning support facilities during the covid 19 pandemic in Indonesia, East Kalimantan. Thus, this study aims to provide motivation, solutions, and recommendations for educators with shortages and obstacles to teaching online during the covid-19 pandemic in elementary schools. 


\section{Method}

The research was conducted through the descriptive qualitative method, using the phenomenological approach (Creswell, 2019, p. 18). The research took place at a palm oil plantation school in East Kalimantan. The research procedure went through three stages; namely, 1) pre-field. The researcher looked at the conditions and planned research in the field and asked for approval from the exemplary company prima group as the research's elementary school institution manager. 2) The study's implementation, researchers, researched by taking research data using observation techniques, interviews, and documentation, 3 ) stages of field data analysis, this step as a step in testing the validity of field data (Lexy J, 2007, p. 126).

The subjects involved three teachers at two elementary schools in disadvantaged areas, namely SD Teladan Prima Benua Baru, Muara Bengkal Subdistrict, East Kutai Regency SD Teladan Prima 01 Talisayan, Berau, East Kalimantan. Three teachers were involved in the study, namely the initials WD, SW, and YWF. The research object focuses on the adaptation process of new learning and methods of solving teacher problems in the learning process during the covid-19 pandemic.

Data retrieval techniques and methods, researchers use observation techniques to implement learning during the covid-19 pandemic and geographic observations of the school environment, in-depth interviews with educators with the initials WD, SW, and YWF, and documentation of educators and school archives. The research time in data collection from October to December 2020.

The validity test of research data triangulates sources from three respondents at two SD Teladan Prima Benua Baru and SD Teladan Prima 01 Talisayan, namely WD, SW, and YWF. The same questions about the learning process during the covid-19 pandemic, the problems or obstacles faced during distance learning, and creative innovations to learn in the covid-19 era. Data analysis using Miles \&Huberman consists of three activities: data reduction, data presentation, conclusion drawing. The information obtained is tabulated, summarized, and comprehensively explained.

\section{Result and Discussion}

All respondents carried out teaching activities according to the guidance from the local authorities along with school policies. Generally, even though teaching/learning activities were carried out online, teachers still need to carry out offline guiding and monitoring to the students. However, the meeting frequency and duration were much reduced. According to teachers' reports, there were various problems in the application of online learning. Teachers also tried to apply some problem-solving strategies to cope with the unfavorable situation. The following sections summarize the problems faced and coping strategies applied by the teachers.

Table 1. Field research results

\begin{tabular}{ll}
\hline \multicolumn{1}{c}{$\begin{array}{c}\text { Problems in The Implementation of Online } \\
\text { Learning }\end{array}$} & \multicolumn{1}{c}{ Teachers' Problem-Solving Strategies } \\
\hline Smartphone ownership and network coverage & $\begin{array}{l}\text { Combination of online and offline teaching/learning } \\
\text { method (blended learning) }\end{array}$ \\
TV and radio networks are not reachable & $\begin{array}{l}\text { Creating study group } \\
\text { Teaching materials }\end{array}$ \\
Degular visitation \\
Students discipline & Involving and cooperating with parents \\
Parents' competence & Adaptation of teaching plan \\
Time limitation & Optimizing electronic media \\
\hline
\end{tabular}

Source:Processed field data, 2020

Problems in delivering appropriate teaching were expressed by respondents. The problems are expressed as follows: Smartphone ownership and network coverage. Ownership of smartphones is the most common problem found by respondents. Not all students or their parents have smartphones. WD and DW said that "not all of the students' parents have android phones, as well as the limitation of network coverage, forced teachers to carry out offline teaching/learning". YWF on the other side stated that "students and their parents need to find a spot with appropriate internet connection in order to obtain information of the lesson and to send the assignments". This shows that the infrastructure is not appropriate to carry out online classes. 
TV and radio networks are not reachable. Learning through TV and radio is an alternative to online learning. It is much cheaper since it does not require a data plan. However, even this could not be accessed in some locations. "Since we live in the outermost, frontier area, we cannot access education program through TV nor radio" (WD).

Teaching materials. Teaching materials became a problem due to the change in the learning environment. YWF stated that "we do not have an English handbook that matches the lesson plan and syllabus" and "currently for the 2013 curriculum, there is no appropriate learning media for English subject for elementary school that contains thematic content".

Distance also became a problem in carrying out offline learning. "The students live in different divisions that are far one to the other" (YWF). Therefore, visitation to the study groups was timeconsuming.

Students' discipline was another problem faced during offline and online learning. It was mostly found in kindergarten. WD stated that "when the teacher comes, the student is not ready for learning or still sleeping" and "students are not focused to learn" were found during teachers' visitation, and "parents complain about children plays more with the smartphone" which refers to the activity outside class period. This issue needs to be taken into concern since it may affect students' character in long-life learning. Indiscipline behavior was also found by YWF, who stated that "smartphones that supposed to be used to learn frequently used to play games and social media".

Parents' competence, Due to the "study from home" policy, parents had to act as teachers to their children. However, it became another burden for them. "Parents are obliged to be teachers for their own children by perforce, while they have different education background" (YWF). As the impact, the obligation was back to the teachers.

Time limitation, Due to the limitation of resources as well as parents' competence, teachers need to visit the students in the study group regularly. However, it should be carried out by considering various factors, including the number of groups to be visited, and the effort to hinder prolonged crowd. As the result, the class meeting was shortened. "Teaching/learning activity is limited to only one hour in offline class" (YWF).

Teachers' problem-solving strategies Faced with various obstacles in performing education during the Covid-19 pandemic, teachers are expected to have the appropriate problem-solving skill to cope with the problems. The result of this research showed the respondents' strategy to cope with the problems, including:

Combination of online and offline teaching/learning method (blended learning). Due to the restriction policy released by the government and public fear of Covid-19 transmission, teaching/learning activity was only allowed to be done online. However, it was not applicable due to the limitation of infrastructure as well as teachers, students, and parents' competence. Therefore, teaching/learning activity was carried out online and offline. SW stated that "In order to deliver effective teaching to the students, our school carry out online and offline teaching/learning according to necessities". Another statement was made by YWF: "Since the teaching/learning activity is allowed, the school decided to carry out both online and offline teaching/learning in the new semester (second semester during Covid-19 pandemic)".

Creating a study group was the most common strategy applied by the respondents. Some statements were obtained from the respondents, such as: "In order to perform offline teaching/learning, students are grouped into several groups consisted of $2-3$ children with the nearby living area" (WD), "In order to make students easier to understand and do their home-work, I asked 5 - 6 students with nearby homes to gather in one house on the day I give assignment" (YWF), and "In the new semester, since the offline teaching/learning is allowed, the school decided to create study groups with 8 - 10 members per group" (YWF).

Regular visitation, Sudden transformation of teaching/learning activity from offline to online caused shock to the teachers, students, and parents. As the impact, either teachers, students, and parents had difficulties in performing education. Therefore, teachers carried out regular visitation to the students although the impact could not match the regular class. Respondents stated that "Teachers regularly visit students' home to check and carry out learning guidance" (WD), and "Visitation was carried out according to schedule that has been arranged" (YWF). Those statements showed that teachers gave more effort as a part of their responsibility in educating children.

Involving and cooperating with parents, Parents' involvement was absolute during the study from home policy. However, the involvement may be different according to teachers' perspectives. SW for example stated that "Periodically, teachers will send learning guidance and materials for home-learning to parents so that they can help their children in their study". While YWF stated that "I asked parents to send a 
photo of their children while they are doing their home-work". Another statement was expressed by WD "Parents are involved to assist their children in the offline learning".

Adaptation of teaching plan was also carried out to cope with the disruption faced due to the Covid-19 pandemic. "Since the curriculum cannot be delivered whole fully during Covid-19 pandemic, we adapted the learning props and materials to the actual condition" (YWF). This emphasized the impact of the pandemic on education disruption.

Optimizing electronic media. Electronic media became one of the options to enrich learning materials. Respondents' statements included "We recommend parents to utilize TV that contain education broadcast such as TVRI as a source of learning materials" (SW) and "I collected teaching materials from the internet, specifically ESL, to obtain teaching materials that fit the lesson topic" (YWF).

Utilization of creative learning media. Creativity is an important aspect to carry out education appropriately. There are various methods available to be utilized in teaching activities. Among the creative methods used by the respondents are: "Every Friday I send video to the chat group to say hi to the students and other teachers" (SW); "I took students to a nearby chicken farm and used it as teaching materials during lesson hour to make the learning activity fun and easier to be understood, and sometimes use the educational game" (YWF); "Since we live in a remote area, we use only available teaching/learning materials such as independent learning module, worksheet, printed learning materials, props, and learning media from the surrounding" (WD).

\section{Discussion}

Obstacles in teaching \& learning activity all around the world. Due to the Covid-19 global pandemic, Emergency Distance Education (EDE) was implemented as an emergency measure to cope with the disruption in education. In Indonesia, it was implemented through an online teaching/learning policy (Giatman, Siswati, \& Basri, 2020, p. 169). Unfortunately, the infrastructures and facilities were unprepared, causing ineffective application of online learning. The lacking infrastructures and facilities that caused obstacles in delivering online learning are also reported in many regions in Indonesia (Sukiastini, 2020, p. 386).

The results of the research of two elementary school institutions in east Kalimantan Indonesia showed various obstacles in the implementation of learning during the covid-19 pandemic. Some of the obstacles encountered by researchers include: Smartphone ownership and network coverage, UNreachable TV and radio networks, Teaching materials, Mileage, Student discipline, Parental Competence, Time Limitations.

Related to smartphone ownership, indonesian society is still constrained by smarthphone ownership. Problems related to smartphone ownership is frequently found in Indonesia's society (Atsani, 2020, p. 88; Napitupulu, 2020, p. 27). This could be found due to various factors, such as economic capacity, unfamiliarity, or simply because they never thought that they would need it. Smartphone becomes an important tool in delivering online education during the Covid-19 pandemic in Indonesia, since many stakeholders prefer using the phone-based platform, specifically WhatsApp, to email-based apps such as zoom or google classroom (Gunawan, Suranti, \& Fathoroni, 2020, p. 63). Therefore, teachers and school managers are supposed to use more flexible tools to use in online teaching/learning activities.

The coverage of mobile networks as well as electronic media such as TV and radio became another obstacle in online education (Lau et al., 2020, p. 4). This is due to the slow and uneven infrastructure and facilities development brought by the government (Khadijah, 2021, p. 64). Unfortunately, this problem needs the government's involvement or any related stakeholders. Therefore, teachers and school managers need to find alternative methods to cope with the problems.

Limitation of teaching materials is also found in many regions, especially in remote areas (Kusumastuti, Meskill, \& Guo, 2020, p. 2; Nugroho \& Atmojo, 2020, p. 237). This could be due to the changing curriculum, or simply because students are not prepared with handbooks. However, teachers should at least have certain materials for their previous teaching activities. Unfortunately, teaching activities in many regions still use traditional methods where teachers explain the lesson directly in the class (Rachman, 2019, p. 19). This due to the lack of teaching facilities and unsupportive infrastructures (Fitrianto, 2020, p. 93). Moreover, education in the elementary school should also integrate motoric activities and teachers explain by demonstration (Iline, 2013, p. 53; Sofyan, 2016, p. 31). This could be one of the reasons teachers do not have collections of teaching materials from previous teaching activities.

During the online learning policy, the school management decided to do periodic visitation to students due to the limitation in the implementation of online learning. Unlike in the cities, students' home was scattered, making the visitation harder to carry out and time-consuming. However, it is unavoidable in many areas with undeveloped transportation and communication infrastructures. 
The obstacles due to students' discipline require more attention. Developing students' discipline is one of the purposes of education (Ismail, Rahim, \& Yusoff, 2013, p. 85; Sofyan, 2016). Thus, failure in developing students' discipline is a part of education failure. Lack of students' discipline could be due to the change of education model or due to children's euphoria of using smartphones (Hunaida \& Izmiyah, 2020, p. 403). Changes in educational practice, such as uncertainty of school hours and teachers' visitation rather than students' attendance caused students to be laxed (Sukmawati, Pramita, Purba, \& Utami, 2020, p. 79). On the other hand, elementary school students are generally not allowed to use smartphones during school (Machmud, 2018, p. 37), or even at home (Sekarasih, 2016, p. 144). Some students even never know of smartphone and their features. However, since the use of smartphones is obliged in online learning, students' curiosity grew, making them distracted from the original use of the smartphone as a tool for communication.

Since education is delivered online, parents receive more obligation in their children's education (Brom et al., 2020, p. 2). Parents are frequently involved in student's learning, acting as a teacher. Unfortunately, most parents do not have the appropriate competence to be involved in students' education (A. Rahman, 2020, p. 367). Moreover, many parents are not a home parents and busy with their works, making them unable to assist their children (Putra, Liriwati, Tahrim, Syafrudin, \& Aslan, 2020, p. 36). Therefore, involving parents as the representatives of teachers is not appropriate.

The method of learning during the covid-19 pandemic, researchers found that in two rural elementary schools in East Kalimantan, Indonesia, there are various solutions in carrying out learning. Methods used during online learning considering the limitations of infrastructure, educators carry out learning using strategies: Combination of online and offline, methods of teaching and learning (blended learning), Creating learning groups, Regular visits, Involving and cooperating with parents, Adaptation of teaching plans, Optimizing electronic media, Utilization of creative learning media.

During the Covid-19 pandemic, some teachers need to carry out education door to door (Aji, 2020, p. 400). To make it easier to organize, classes were divided into some study groups and the learning period was cut off to only one hour. This also aimed to reduce the risk of virus transmission. Therefore, teaching materials were not delivered completely. Teachers need to create adaptive learning materials (Sudrajat, 2020, p. 107) that can be delivered in a short time, cover the lesson topic whole fully, easily understood, doable individually, but need quite a lot of time to work out.

Teachers' problem-solving skill. The implementation of online learning in Indonesia, undoubtedly, faced a lot of obstacles (Rasmitadila et al., 2020). However, these obstacles could not be solved in a short period. In the meantime, disruption caused by the Covid-19 pandemic requires fast response and coping strategies. Therefore, the problem-solving of educational obstacles relied on teachers and educationrelated institutions such as school managers and authorities (Yao, Rao, Jiang, \& Xiong, 2020, p. 522).

Delivering education through blended learning was expected to improve the effectiveness of teaching/learning activity during the Covid-19 pandemic (Rachmadtullah et al., 2020, p. 3275). Elementary school education cannot rely on only online teaching/learning. Students also need to develop their affective skills instead of cognitive skill. Students need direct interaction with the teacher (KirovskaSimjanoska, 2019, p. 41), see teachers demonstrate the materials, develop self-concept, and learn to behave. Learning through online class would lack the practice and guidance that are needed by primary school students (Kim, 2020). Thus, implementation of blended learning is important to avoid significant loss of education.

Dividing the class into study groups was an option chosen by respondents in order to carry out blended learning. With a smaller class size, lessons should be delivered more effectively. However, teachers need to give extra effort to deliver teaching activities to the whole class members. Teachers need to carry out door-to-door teaching, by frequently visit their students to ensure the education goes appropriately (Kaur, Keshri, \& Sharma, 2020, p. 127). Teachers also need to cooperate with parents to monitor their children's learning activities. Therefore, carrying out regular visitation and cooperating with parents are the consequences of the implementation of blended learning.

Disruption of education practice also impacted the realization of the curriculum (Mansyur, 2020, p. 118). Many schools adapted their learning plan to maintain the education activities since achieving the teaching/learning target would not be possible. Even though it could be considered as a loss, but it was better than gaining no knowledge at all (Chick et al., 2020).

Using electronic media could be an option for distance learning, and was chosen as one of the learning media by some respondents (Zhang, Wang, Yang, \& Wang, 2020, p. 3). However, there are limitations to it. Aside from the network coverage, not all TV or radio programs contain educational content. Therefore, learning could only be done at a certain time. Moreover, learning from TV or radio would also need guidance, while teachers also have no idea of what kind of education topic the TV or radio broadcast. Therefore, unless the government has specialized TV or radio channel that only broadcast 
educational content, it would not be effective. Creating creative learning media should be prioritized by teachers in order to cope with the unfavorable condition as aforementioned (Sudrajat, 2020). However, it requires various skills that not all teachers have. Various learning media includes videos, learning handbooks, props. However, since teachers' skills are limited, teachers could cooperate, or cooperate with third party providers.

Improvement of problem-solving skill in education. Referring to the result of this research, respondents tend to have common problem-solving strategies i.e., creating study groups, blended learning, lesson adaptation, teacher-parent cooperation, integration of electronic media, and the usage of creative media. However, the implementation was not effective due to various obstacles. Unfortunately, there were several aspects neglected by teachers, such as time limitation, parents' competence, students' discipline, teaching materials, and limitation of teaching/learning media. The result implied that teachers need to improve their problem-solving skills.

Teachers' problem-solving skills became one of the problems in optimizing education delivery during the Covid-19 pandemic. Problem-solving skill is strongly related to critical thinking skill (Kozikoğlu, 2019, p. 114). Therefore, it requires a strong awareness of the problems as well as the potential solving strategies. Problem-solving skills need to be retrieved through continuous learning and training (Yavuz et al., 2010). Teachers should have the proper understanding to be able to formulate appropriate problem-solving strategies. Certain places such as outermost, least developed areas provide an indigenous environment and socio-culture properties that are useful to improve problem-solving skills (Parmin \& Fibriana, 2019, p. 150).

Implication and Future perspective. School closure is a policy that was expected to prevent the transmission of the virus. However, Viner et al. (2020, p. 397) considered that it is not quite effective in preventing transmission. Due to the school closure, students may avoid contact with their schoolmates, but they tend to shift contacts to non-school communities. Online learning activities is sure cannot replace hands-on experience (Chick et al., 2020). However, it could at least reduce the loss of the learning experience. Even though online learning is applicable, several things need to be taken into concern, especially regarding students' needs. Adnan and Anwar (2020, p. 48) as well as Munastiwi (2020, p. 228) observed students' perspective regarding online learning and found some disadvantages, including technical issues such as bad internet access, motivation issue, difficulties in completing group assignments, and the need of face-to-face interaction to learn properly. Those issues are faced by higher education students. Therefore, the issues faced by elementary school students are supposed to be greater.

Covid-19 pandemic created an emergency in education. This caused a sudden disruption in the educational system. However, what we should learn from the Covid-19 outbreak is that there are possibilities of life disruption in the future, whether it is on a global, national, regional, or local scale. Therefore, a strategic management model is needed to rapidly respond to any disruption and maintain the function of education (Karalis, 2020). Tria (Tria, 2020) suggested the implementation of physical distancing and strengthening the online education platform as standard in education practice even after the Covid-19 pandemic has ceased. Similar to the opinion, Pham and Ho (Pham \& Ho, 2020) suggested that distance learning (online learning or e-learning) is the "new normal" in education during the post-Covid19 pandemic.

In Indonesia, online learning has been adopted by schools, but only in very limited numbers (Lie et al., 2020). Unfortunately, during the Covid-19 pandemic, the government is unprepared for the changes in the education environment that force the widespread implementation of online learning. While another country such as China had a proper preparation (Huang et al., 2020). A covid-19 pandemic may not be the only phenomena that drive the implementation of emergence distance education (EDE). Therefore, education practitioners should consider designing EDE that could be used as a standard response in an emergency in the future (Karataş \& Tuncer, 2020, p. 27). According to Rasmitadila et al. (Rasmitadila et al., 2020), successful online learning implementation requires a flexible curriculum, the readiness of technology, and collaboration. Daniel (Daniel, 2020) suggested the implementation of asynchronous learning and video lessons in distance learning. These methods are considered more flexible to deliver lessons to the students.

Availability of appropriate infrastructures and facilities became the undeniable obstacles to carry out online education. Therefore, the government is obliged to improve the development of infrastructures and facilities that are required to perform online education, such as internet network, especially to the remote area such as outermost and least developed regions. However, the development of infrastructures and facilities are not enough. The government also needs to arrange an online education program that is accessible by any class of society.

As a countermeasure to future disruption in education, the government, as well as education practitioners, need to prepare some alternatives to distance education. The utilization of tv and radio 
broadcasts, as well as the internet, could be alternatives to distance education practices (Huang et al., 2020). The utilization of TV and radio as education media should be easier and cheaper to access than using the internet. Learning from the disruption caused by the Covid-19 pandemic, we should pay more attention to other learning sources. Nowadays, due to the advancement of information and communication technology, there have been many internet TV programs managed by individuals or communities. They provide various information and knowledge, and even curriculum related lessons. Both paid and free access are available. However, since it is internet-based, the viewers would need to spend some money for internet access. Therefore, it could not be accessed by anyone, especially communities which live in the area with limited internet network. However, the government should be able to follow or even develop further the advancement in education models.

The model has been adopted by the Chinese government. In order to cope with the disruption in education due to the Covid-19 pandemic, the Chinese Ministry of Education has implemented the Open Education Resources (OER) and Open Education Practices (OEP) to maintain education process without physical class (Huang et al., 2020). OER refers to the learning resources that are provided by various bodies, including international and national repositories as well as public repositories, while OEP refers to the teaching/learning, collaboration, and assessment activities (Huang et al., 2020). Through the implementation of OER, teachers would have unlimited teaching materials, while students would easily obtain uniform learning materials.

Imbalance of students' competence becomes one of the problems in digital platform integration in distance learning for elementary school (Iivari, Sharma, \& Ventä-Olkkonen, 2020). Unfortunately, lack of competence is not only found in students but also in teachers. Many cases showed that teachers are incompetent in engaging ICT. This could be a huge obstacle for the future educational perspective.

Integration of ICT is important to improve students' learning performance and promote students to learn new technology-based skills that are required in the digital era (Shamir-Inbal \& Blau, 2016, p. 24). The problem concerning teachers, students, and parents' shock in the application of online teaching/learning activities was because they are not accustomed to it. However, the implementation of ICT in elementary school is considered less relevant because teachers and students meet on a daily basis (Blau \& Shamir-Inbal, 2017, p. 778). This makes, especially the students, become unprepared and incapable of using ICT properly and wisely.

Engaging teacher with ICT skills is important to support the development of problem-solving skills. Problem-solving skill is an important skill to cope with the unfavorable condition. It is the skill that everyone needs in the $21^{\text {st }}$ century (M. M. Rahman, 2019). However, due to the rapid advancement of technology, there will also be a rapid change in education obstacles. Therefore, being unprepared would not be an option. In order to improve teachers' problem-solving skills, there needs an improvement in problem-based learning in teacher training (Güleç, 2020, p. 53; Yavuz et al., 2010). Stakeholders such as the government, school foundations, as school managers need to actively hold problem-solving skill training.

\section{Conclusion}

The Covid-19 pandemic had caused disruption in elementary school education in East Kalimantan Province. Unfortunately, the effort to implement online education also faced various obstacles, such as inappropriate infrastructures and facilities, parents' incompetence, students' discipline, and limitation of teaching/learning materials. In order to cope with the problems, teachers made some effort to keep the education activity going such as carrying out blended learning, cooperating with parents, and utilization of alternative teaching media. However, the solution provided by the teachers did not cover all the problems they found. Therefore, there need to be further improvement of teachers' problem-solving skill.

\section{References}

Adnan, M., \& Anwar, K. (2020). Online learning amid the COVID-19 pandemic: Students perspectives. Journal of Pedagogical Sociology and Psychology, 1(2), 45-51. https://doi.org/10.33902/JPSP.2020261309

Aji, R. H. S. (2020). Dampak Covid-19 pada Pendidikan di Indonesia: Sekolah, Keterampilan, dan Proses Pembelajaran. SALAM: Jurnal Sosial Dan Budaya Syar-I, 7(5), 395-402. https://doi.org/10.15408/sjsbs.v7i5.15314

Atsani, K. L. G. M. Z. (2020). Transformasi media pembelajaran pada masa pandemi Covid-19 (Transformation of learning media during Covid-19 pandemic). Al-Hikmah: Jurnal Studi Islam, 
1(1), 82-93.

Benke, C., Autenrieth, L. K., Asselmann, E., \& Pané-Farré, C. A. (2020). Lockdown, quarantine measures, and social distancing: Associations with depression, anxiety and distress at the beginning of the COVID-19 pandemic among adults from Germany. Psychiatry Research, 293. https://doi.org/10.1016/j.psychres.2020.113462

Berawi, M. A. (2020). Empowering healthcare, economic, and social resilience during global pandemic Covid-19. International Journal of Technology, 11(3), 436-439. https://doi.org/10.14716/ijtech.v11i3.4200

Blau, I., \& Shamir-Inbal, T. (2017). Digital competences and long-term ICT integration in school culture: The perspective of elementary school leaders. Education and Information Technologies, 22(3), 769-787. https://doi.org/10.1007/s10639-015-9456-7

Brom, C., Lukavský, J., Greger, D., Hannemann, T., Straková, J., \& Švaříček, R. (2020). Mandatory Home Education During the COVID-19 Lockdown in the Czech Republic: A Rapid Survey of 1st-9th Graders' Parents. Frontiers in Education, 5(July), 1-8. https://doi.org/10.3389/feduc.2020.00103

Chick, R. C., Clifton, G. T., Peace, K. M., Propper, B. W., Hale, D. F., Alseidi, A. A., \& Vreeland, T. J. (2020). Using Technology to Maintain the Education of Residents During the COVID-19 Pandemic. Journal of Surgical Education. https://doi.org/10.1016/j.jsurg.2020.03.018

Creswell, J.w. (2019). Research Design (4th ed.). Yogyakarta: pustaka pelajar.

Daniel, S. J. (2020). Education and the COVID-19 pandemic. Prospects, 49(1-2), 91-96. https://doi.org/10.1007/s11125-020-09464-3

Dong, C., Cao, S., \& Li, H. (2020). Young children's online learning during COVID-19 pandemic: Chinese parents' beliefs and attitudes. Children and Youth Services Review, 118, 105440. https://doi.org/10.1016/j.childyouth.2020.105440

Fitrianto, H. (2020). The Roles of Islamic Education in Building Self-Regulated Learner in the Era of Distance Education. At-Ta'dib, 15(2), 84-108. https://doi.org/10.21111/at-tadib.v15i2.4825

Garbe, A., Ogurlu, U., Logan, N., \& Cook, P. (2020). Covid-19 and remote learning: Experiences of parents with children during the pandemic. American Journal of Qualitative Research, 4(3), 45-65. https://doi.org/10.29333/ajqr/8471

Giatman, M., Siswati, S., \& Basri, I. Y. (2020). Online Learning Quality Control in the Pandemic Covid-19 Era in Indonesia. Journal of Nonformal Education, 6(2), 168-175. https://doi.org/https://doi.org/10.15294/jne.v6i2.25594

Güleç, S. (2020). Problem Solving Skills in Social Studies Education and Problem Solving Skills of Social Studies Teachers. Journal of Education and Training Studies, 8(3), 48. https://doi.org/10.11114/jets.v8i3.4686

Gunawan, Suranti, N. M. Y., \& Fathoroni. (2020). Variations of models and learning platforms for prospective teachers during the Covid-19 pandemic period. Indoneisan Journal of Teacher Education, 1(2), 61-70.

Huang, R., Tlili, A., Chang, T.-W., Zhang, X., Nascimbeni, F., \& Burgos, D. (2020). Disrupted classes, undisrupted learning during COVID-19 outbreak in China: application of open educational $\begin{array}{lllll}\text { practices and resources. Smart Learning Environments, } & 7(1),\end{array}$ https://doi.org/10.1186/s40561-020-00125-8

Hunaida, W. L., \& Izmiyah, M. (2020). Electability of Online Learning in the Perspective of Parents at MI Plus Al-Mahmud During the Covid-19 Pandemic. Journal of Islamic Education, 8(2), 397-420. https://doi.org/10.30762/didaktika.v8i2.2706

Iivari, N., Sharma, S., \& Ventä-Olkkonen, L. (2020). Digital transformation of everyday life - How COVID-19 pandemic transformed the basic education of the young generation and why information management research should care? International Journal of Information Management, 55, 102183. https://doi.org/10.1016/j.ijinfomgt.2020.102183

Iline, C. S. (2013). Impacts of the Demonstration Method in the Teaching and Learning of Hearing Impaired 
Children. IOSR Journal of Humanities and Social Science, 12(1), 48-54. https://doi.org/10.9790/0837-1214854

Inawati, L., \& Setyowati, L. (2020). The Students' and Parents Voices on Online Learning in SMP Wahid Hasyim Pasuruan. Linguista: Jurnal Ilmiah Bahasa, Sastra, Dan Pembelajarannya, 4(2), 120-127. https://doi.org/http://doi.org/10.25273/linguista.v4i2.8126

Ismail, M., Rahim, P. R. M. A., \& Yusoff, M. S. M. (2013). Educational Strategies to Develop Discipline among Students from the Islamic Perspectives. Procedia - Social and Behavioral Sciences, 107, 80-87. https://doi.org/10.1016/j.sbspro.2013.12.402

Jennings, J. L., \& DiPrete, T. A. (2010). Teacher Effects on Social and Behavioral Skills in Early Elementary School. Sociology of Education, 83(2), 135-159. https://doi.org/10.1177/0038040710368011

Karalis, T. (2020). Planning and evaluation during educational disruption: Lessons learned from Covid-19 pandemic for treatment of emergencies in education. European Journal of Education Studies, 7(4), 125-142. https://doi.org/10.5281/zenodo.3789022

Karataş, T. Ö., \& Tuncer, H. (2020). Sustaining Language Skills Development of Pre-Service EFL Teachers despite the COVID-19 Interruption: A Case of Emergency Distance Education. Sustainability, 12(19), 8188. https://doi.org/10.3390/su12198188

Kaur, H., Keshri, R., \& Sharma, A. (2020). Casualties Caused by COVID-19 on Education System. International Journal For Research in Applied Sciences and Biotechnology, 7(5), 125-133. https://doi.org/10.31033/ijrasb.7.5.18

Khadijah, I. (2021). The Competency of Science Teachers in Implementation of Online Learning in Covid19 Pandemic Period at SMPN 2 Kramatwatu Serang. Bulletin of Science Education, 1(1), 60-67.

Khanna, R., \& Kareem, D. J. (2021). Creating inclusive spaces in virtual classroom sessions during the COVID pandemic: An exploratory study of primary class teachers in India. International Journal of Educational Research Open, 2-2, 100038. https://doi.org/10.1016/j.ijedro.2021.100038

Kim, J. (2020). Learning and Teaching Online During Covid-19: Experiences of Student Teachers in an Early Childhood Education Practicum. International Journal of Early Childhood, 52(2), 145-158. https://doi.org/10.1007/s13158-020-00272-6

Kirovska-Simjanoska, D. (2019). Digital vs in-Person Learning Environment in ESP Classrooms: Let the Students Decide. SEEU Review, 14(1), 36-68. https://doi.org/10.2478/seeur-2019-0004

Koh, W. C., Naing, L., \& Wong, J. (2020). Estimating the impact of physical distancing measures in containing COVID-19: An empirical analysis. International Journal of Infectious Diseases, 100, 42 49. https://doi.org/10.1016/j.ijid.2020.08.026

Kozikoğlu, İ. (2019). Investigating critical thinking in prospective teachers: Metacognitive skills, problem solving skills and academic self-efficacy. Journal of Social Studies Education Research, 10(2), 111-130.

Kusumastuti, W. P., Meskill, C., \& Guo, D. (2020). Innovative Hybrid Responses to Emergency Remote Learning in Rural Indonesia. 13th Innovation in Language Learning International Conference, 14.

Lapitan, L. D., Tiangco, C. E., Sumalinog, D. A. G., Sabarillo, N. S., \& Diaz, J. M. (2021). An effective blended online teaching and learning strategy during the COVID-19 pandemic. Education for Chemical Engineers, 35, 116-131. https://doi.org/10.1016/j.ece.2021.01.012

Lassoued, Z., Alhendawi, M., \& Bashitialshaaer, R. (2020). An Exploratory Study of the Obstacles for Achieving Quality in Distance Learning during the COVID-19 Pandemic. Education Sciences, 10(9), 232. https://doi.org/10.3390/educsci10090232

Lau, L. L., Hung, N., Go, D. J., Ferma, J., Choi, M., Dodd, W., \& Wei, X. (2020). Knowledge, attitudes and practices of COVID-19 among income-poor households in the Philippines: A cross-sectional study. Journal of Global Health, 10(1). https://doi.org/10.7189/jogh.10.011007

Lexy J, M. (2007). Metodologi Penelitian Kualitatif. Bandung: Rosdakarya.

Lie, A., Tamah, S. M., Gozali, I., Triwidayati, K. R., Utami, T. S. D., \& Jemadi, F. (2020). Secondary School Language Teachers' Online Learning Engagement during the Covid-19 Pandemic in Indonesia. 
Journal of Information Technology Education: Research, 19, 803-832. https://doi.org/10.28945/4626

Ma, S., Sun, Z., \& Xue, H. (2020). Childcare Needs and Parents' Labor Supply: Evidence from the COVID -19 Lockdown. SSRN Electronic Journal. https://doi.org/10.2139/ssrn. 3630842

Ma, X., Shen, J., Krenn, H. Y., Hu, S., \& Yuan, J. (2016). A Meta-Analysis of the Relationship Between Learning Outcomes and Parental Involvement During Early Childhood Education and Early Elementary Education. Educational Psychology Review, 28(4), 771-801. https://doi.org/10.1007/s10648015-9351-1

Machmud, K. (2018). The Smartphone Use in Indonesian Schools: The High School Students' Perspectives. Journal of Arts and Humanities, 7(3), 33. https://doi.org/10.18533/journal.v7i3.1354

Mansyur, A. R. (2020). Dampak COVID-19 Terhadap Dinamika Pembelajaran Di Indonesia. Education and Learning Journal, 1(2), 113-123. https://doi.org/10.33096/eljour.v1i2.55

Marroquín, B., Vine, V., \& Morgan, R. (2020). Mental health during the COVID-19 pandemic: Effects of stayat-home policies, social distancing behavior, and social resources. Psychiatry Research, 293. https://doi.org/10.1016/j.psychres.2020.113419

Muhdi, Nurkolis, \& Yuliejantiningsih, Y. (2020). The Implementation of Online Learning in Early Childhood Education During the Covid-19 Pandemic. JPUD - Jurnal Pendidikan Usia Dini, 14(2), 247-261. https://doi.org/10.21009/JPUD.142.04

Munastiwi, E. (2020). Colorful Online Learning Problem of Early Childhood Education During the Covid-19 Pandemic. $A^{\prime}$-Ta'lim Joutnal, 27(3), 227-235. https://doi.org/10.15548/jt.v27i3.663

Mutlu Göcmen, N., \& Gülec, S. (2018). Relationship between Teachers' Perceptions of Mobbing and Their Problem Solving Skills. Educational Research and Reviews, 13(1), 51-59. https://doi.org/10.5897/ERR2017.3284

Napitupulu, R. M. (2020). Dampak pandemi Covid-19 terhadap kepuasan pembelajaran jarak jauh (Impact of Covid-19 pandemic to distance learning satisfaction). Jurnal Inovasi Teknologi Pendidikan, 7(1), 23-33. https://doi.org/10.21831/jitp.v7i1.32771

Nugroho, A., \& Atmojo, A. E. P. (2020). Digital Learning of English Beyond Classroom: EFL Learners' Perception and Teaching Activities. Journal of English Education and Lingusitics Studies, 7(2), 219-243. https://doi.org/https://doi.org/10.30762/jeels.v7i2.1993

Parmin, P., \& Fibriana, F. (2019). Prospective Teachers' Scientific Literacy through Ethnoscience Learning Integrated with the Indigenous Knowledge of People in the Frontier, Outermost, and Least Developed Regions. Jurnal Penelitian Dan Pembelajaran IPA, 5(2), 142-154. https://doi.org/10.30870/jppi.v5i2.6257

Pham, H. H., \& Ho, T. T. H. (2020). Toward a 'new normal' with e-learning in Vietnamese higher education during the post COVID-19 pandemic. Higher Education Research and Development, 39(7), 13271331. https://doi.org/10.1080/07294360.2020.1823945

Prestiadi, D. (2020). Effectiveness of e-learning implementation as a distance learning strategy during coronavirus disease (covid-19) pandemic. Proceeding "International Webinar on Education 2020", 47-53.

Putra, P., Liriwati, F. Y., Tahrim, T., Syafrudin, S., \& Aslan, A. (2020). The Students Learning from Home Experiences during Covid-19 School Closures Policy In Indonesia. Jurnal Iqra': Kajian Ilmu Pendidikan, 5(2), 30-42. https://doi.org/10.25217/ji.v5i2.1019

Rachmadtullah, R., Subandowo, M., Rasmitadila, Humaira, M. A., Aliyyah, R. R., Samsudin, A., \& Nurtanto, M. (2020). Use of blended learning with moodle: Study effectiveness in elementary school teacher education students during the COVID-19 pandemic. International Journal of Advanced Science and Technology, 29(7), 3272-3277.

Rachman, A. (2019). Indonesian Primary School Teacher Methods for the Thematic Learning of Kurikulum 2013: A Case Study. Journal of Educational Administration and Leadership Journal, 1(1), 15-23.

Rahman, A. (2020). Family Resilience in Islamic Perspective (A Case Study of Parent and Child Interaction Behavior in the District of Somba Opu Gowa). Jurnal Adabiyah, 20(2), 351-370. 
Rahman, M. M. (2019). 21st Century Skill "Problem Solving": Defining the Concept. Asian Journal of Interdisciplinary Research, 2(1), 64-74. https://doi.org/10.34256/ajir1917

Rasmitadila, R., Aliyyah, R. R., Rachmadtullah, R., Samsudin, A., Syaodih, E., Nurtanto, M., \& Tambunan, A. R. S. (2020). The Perceptions of Primary School Teachers of Online Learning during the COVID-19 Pandemic Period: A Case Study in Indonesia. Journal of Ethnic and Cultural Studies, 7(2), 90. https://doi.org/10.29333/ejecs/388

Sekarasih, L. (2016). Restricting, Distracting, and Reasoning: Parental Mediation of Young Children's Use of Mobile Communication Technology in Indonesia. In S. S. Lim (Ed.), Mobile Communication and the Family (pp. 129-146). https://doi.org/10.1007/978-94-017-7441-3_8

Shamir-Inbal, T., \& Blau, I. (2016). Developing Digital Wisdom by Students and Teachers. Journal of $\begin{array}{llrl}\text { Educational Computing } \quad \text { Research, } & \text { 967-996. }\end{array}$ https://doi.org/10.1177/0735633116649375

Skouteris, H., Watson, B., \& Lum, J. (2012). Preschool Children's Transition to Formal Schooling: The Importance of Collaboration between Teachers, Parents and Children. Australasian Journal of Early Childhood, 37(4), 78-85. https://doi.org/10.1177/183693911203700411

Sofyan, H. (2016). The Increase of Early Childhod's Motoric Development with Thematic Approach. Indonesian Journal of Early Childhood Education Studies, 5(1), 29-37. https://doi.org/10.15294/ijeces.v5i1.10223

Sudrajat, J. (2020). Kompetensi Guru Di Masa Pandemi Covid-19 (Teachers' Competence During Covid-19 Pandemic). Jurnal Riset Ekonomi Dan Bisnis, 13(1), 100-110. https://doi.org/http://dx.doi.org/10.26623/jreb.v13i2.2434

Sukiastini, I. G. A. N. K. (2020). Dunia Pendidikan di Wilayah Pedalaman Papua Sebelum dan Setelah $\begin{array}{llll}\text { Terdampak } \quad \text { Covid-19. Syntax } & \text { Idea, }\end{array}$ https://doi.org/https://doi.org/10.36418/syntax-idea.v2i8`.497

Sukmawati, R. A., Pramita, M., Purba, H. S., \& Utami, B. (2020). The Use of Blended Cooperative Learning Model in Introduction to Digital Systems Learning. Indonesian Journal on Learning and Advanced Education (IJOLAE), 2(2), 75-81. https://doi.org/10.23917/ijolae.v2i2.9263

Tria, J. Z. (2020). The COVID-19 Pandemic through the Lens of Education in the Philippines: The New Normal. International Journal of Pedagogical Development and Lifelong Learning, 1(1), ep2001. https://doi.org/10.30935/ijpdll/8311

Viner, R. M., Russell, S. J., Croker, H., Packer, J., Ward, J., Stansfield, C., ... Booy, R. (2020). School closure and management practices during coronavirus outbreaks including COVID-19: a rapid systematic review. The Lancet Child \& Adolescent Health, 4(5), 397-404. https://doi.org/10.1016/S23524642(20)30095-X

Yao, J., Rao, J., Jiang, T., \& Xiong, C. (2020). What Role Should Teachers Play in Online Teaching during the COVID-19 Pandemic? Evidence from China. Science Insights Education Frontiers, 5(2), 517-524. https://doi.org/10.15354/sief.20.ar035

Yavuz, G., Arslan, C., \& Gulten, D. C. (2010). The perceived problem solving skills of primary mathematics and primary social sciences prospective teachers. Procedia - Social and Behavioral Sciences, 2(2), 1630-1635. https://doi.org/10.1016/j.sbspro.2010.03.249

Zhang, W., Wang, Y., Yang, L., \& Wang, C. (2020). Suspending Classes Without Stopping Learning: China's Education Emergency Management Policy in the COVID-19 Outbreak. Journal of Risk and Financial Management, 13(3), 55. https://doi.org/10.3390/jrfm13030055 